\title{
OPTIMIZATION OF MACHINING PARAMETERS IN FACE MILLING USING MULTI-OBJECTIVE TAGUCHI TECHNIQUE
}

\author{
Yusuf FEDAI, Funda KAHRAMAN, Hediye KIRLI AKIN, Gokhan BASAR
}

\begin{abstract}
In this research, the effect of machining parameters on the various surface roughness characteristics (arithmetic average roughness $(R a)$, root mean square average roughness $(R q)$ and average maximum height of the profile $(R z)$ ) in the milling of AISI 4140 steel were experimentally investigated. Depth of cut, feed rate, cutting speed and the number of insert were considered as control factors; $R a, R z$ and $R q$ were considered as response factors. Experiments were designed considering Taguchi $L_{9}$ orthogonal array. Multi signal-to-noise ratio was calculated for the response variables simultaneously. Analysis of variance was conducted to detect the significance of control factors on responses. Moreover, the percent contributions of the control factors on the surface roughness were obtained to be the number of insert $(71.89 \%)$, feed $(19.74 \%)$, cutting speed (5.08\%) and depth of cut (3.29\%). Minimum surface roughness values for $R a, R z$ and $R q$ were obtained at $325 \mathrm{~m} / \mathrm{min}$ cutting speed, $0.08 \mathrm{~mm} / \mathrm{rev}$ feed rate, 1 number of insert and $1 \mathrm{~mm}$ depth of cut by using multi-objective Taguchi technique.
\end{abstract}

Keywords: milling; optimization; surface roughness; Taguchi

\section{INTRODUCTION}

Machining processes like turning, milling, drilling and grinding, etc., have been commonly used in the manufacturing industries. Milling is one of the basic machining processes using rotary tools to remove material from a workpiece by feeding the tools into the workpiece at a certain direction [1]. Milling is a system consisting of a workpiece, cutting tool, machine tool, fixture and cutting parameters. The machinability of a material is defined by measuring factors such as tool life, cutting force and surface roughness. Surface roughness is a commonly encountered problem in machined surfaces. The quality of the surface plays a very important role in the performance of the milling as a milled surface of good quality significantly improves fatigue strength, corrosion resistance or creep life. Surface roughness is determined using $R a, R z$ and $R q$ measurements $[2,3]$.

At the present time, there have been many investigation progressions in surface roughness modeling and optimization of the machining parameters. Kivak [4] studied the effect of cutting tools, cutting speed and feed rate on the surface roughness and flank wear in milling of Hadfield steel using Taguchi method (TM). Stipkovic Filho et al. [5] developed a mathematical model for surface roughness as a function of cutting speed, feed and cutting depth in face milling of AISI 4140 hardened steel using response surface methodology (RSM). Sarıkaya et al. [6] researched the influence of machining parameters on surface roughness and tool life in face milling process of AISI D3 steel with carbide coated inserts using TM. Ghani et al. [7] optimized machining conditions in end milling process AISI H13 hardened steel using TM. Gopalsamy [8] used TM to find optimal process parameters on surface roughness and tool life for end milling hardened steel. Ab. Rashid et al. [9] applied artificial neural network and multiple regression method for modeling and optimizing of surface roughness. Patwari et al. [10] modelled and optimized machining parameters for surface roughness in end milling of medium carbon steel by using RSM and genetic algorithm. Baek et al. [11] optimized machining parameters in face milling operation of AISI 1041 steel. Benardos and Vosniakos [12] predicted surface roughness in $\mathrm{CNC}$ face milling using neural networks and Taguchi's design of experiments. Routara et al. [13] investigated the influence of cutting parameters: spindle speed, depth of cut and feed rate on the surface roughness of aluminum, brass and AISI 1040 steel in $\mathrm{CNC}$ end milling using RSM. Chhabada and Ambekar [14] used grey relational analysis to multi-response optimization of machining parameters on $\mathrm{CNC}$ milling of EN 19 alloy steel with TiAlN coated cutter. Mansour and Abdalla [15] used RSM for modeling surface roughness in end milling of EN 32 case hardening steel. Gologlu and Sakarya [16] investigated the effects of cutter path strategies on surface roughness of pocket milling of 1.2738 steel based on TM. Gupta and Sood [17] studied the effects of machining parameters on cutting force and surface roughness in turning of AISI 4340 steel using uncoated carbide insert. Taguchi technique and the utility concept were used for the determination of the optimal performance characteristics. They found that cooling condition has a dominant effect on the performance characteristics.

In this study, the effect of machining parameters on the various surface roughness characteristics; $R a, R q$ and $R z$ in the milling of AISI 4140 steel with TiAlN+TiN, PVDcoated, R 390-11 T308M-PM 1030 solid carbide insert were experimentally investigated. Optimal machining parameters were determined using multi-objective Taguchi technique and a confirmation experiment was conducted to test the success of the optimization.

\section{MATERIALS AND METHODS}

Experiments were conducted in dry cutting conditions by using a SPINNER MVC1000 model CNC milling machine. The workpiece material used was AISI 4140 steel in the form of a $260 \times 150 \times 25 \mathrm{~mm}$ block. The chemical composition and mechanical properties of AISI 4140 steel 
are given in Table 1. R 390-020B20-11M tool holder and a TiAlN+TiN, PVD-coated, R 390-11 T308M-PM 1030 solid carbide insert were used. The experimental set up is displayed in Fig. 1. The surface roughness characteristics; $\mathrm{Ra}, \mathrm{Rz}$ and $\mathrm{Rq}$ values of workpieces were measured by MITUTOYO SJ-400 transportable surface roughness tester. The cut off length and evaluation length were constant at $0.8 \mathrm{~mm}$ and $4 \mathrm{~mm}$ respectively. Surface roughness measurements were made three times on the surfaces of workpieces, and their average roughness parameters were determined. Experiments were conducted according to the Taguchi $\mathrm{L}_{9}$ orthogonal design matrix and the results were evaluated using Minitab 17 software.

Table 1 The chemical compositions and mechanical properties of AISI 4140 workpiece material

\begin{tabular}{|c|c|c|c|c|c|}
\hline \multicolumn{7}{|c|}{ Chemical compositions (wt.\%) } \\
\hline $\mathrm{C}$ & $\mathrm{Si}$ & $\mathrm{Mn}$ & $\mathrm{P}$ & $\mathrm{S}$ & $\mathrm{Ti}$ \\
\hline 0.378 & 0.223 & 0.688 & 0.015 & 0.007 & 0.007 \\
\hline $\mathrm{Al}$ & $\mathrm{Cr}$ & $\mathrm{Mo}$ & $\mathrm{Ni}$ & $\mathrm{V}$ & $\mathrm{Co}$ \\
\hline 0.018 & 0.970 & 0.199 & 0.032 & 0.010 & 0.009 \\
\hline \multicolumn{7}{|c|}{ Mechanical properties } \\
\hline $\begin{array}{c}\text { Tensile } \\
\text { strength }\end{array}$ & $\begin{array}{c}\text { Yield } \\
\text { strength }\end{array}$ & $\begin{array}{c}\text { Elongation } \\
(\%)\end{array}$ & $\begin{array}{c}\text { Brinell } \\
\text { Hardness }\end{array}$ & $\begin{array}{c}\text { Elastic } \\
\text { modulus }\end{array}$ & $\begin{array}{c}\text { Poisson } \\
\text { ratio }\end{array}$ \\
\hline $655 \mathrm{MPa}$ & $415 \mathrm{MPa}$ & 25.70 & $197 \mathrm{HB}$ & $\begin{array}{c}190-210 \\
\text { GPa }\end{array}$ & $0.27-0.30$ \\
\hline
\end{tabular}

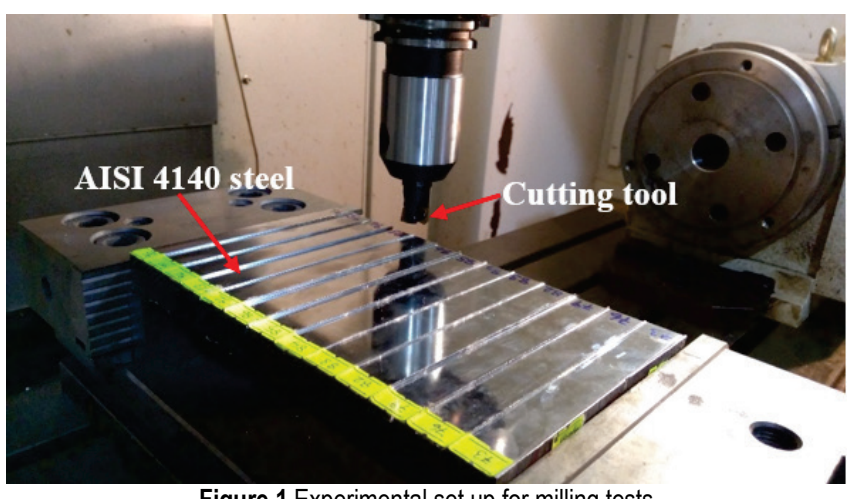

Figure 1 Experimental set up for milling tests

\section{EXPERIMENTAL RESULTS AND DISCUSSION}

Taguchi technique has been widely used in engineering analysis. This technique exhibits a systematic way that is simple and effective in order to optimize designs for cost, performance and quality $[18,19]$. Although the traditional Taguchi technique is successfully applied in the optimization of single response problems, it is not used to solve multi-response problems [20,21].

Multi objective Taguchi method was proposed by Tong et al. [22] and Anthony [23]. This method transforms multiple responses to single response by simply adding normalized quality loss values for analyzing multiple quality characteristics together. Fig. 2 demonstrates the flow chart for the multi objective optimization.

In this study, depth of cut $(\mathrm{mm})$, feed rate $(\mathrm{mm} / \mathrm{rev})$, cutting speed $(\mathrm{m} / \mathrm{min})$ and number of insert (pieces) were chosen as input parameters; the surface roughness characteristics $R a(\mu \mathrm{m}), R q(\mu \mathrm{m})$ and $R z(\mu \mathrm{m})$ were chosen as output parameters. Specified parameters and their levels are given in Tab. 2. Taguchi $\mathrm{L}_{9}$ orthogonal array and experimental results were given in Tab. 3 .

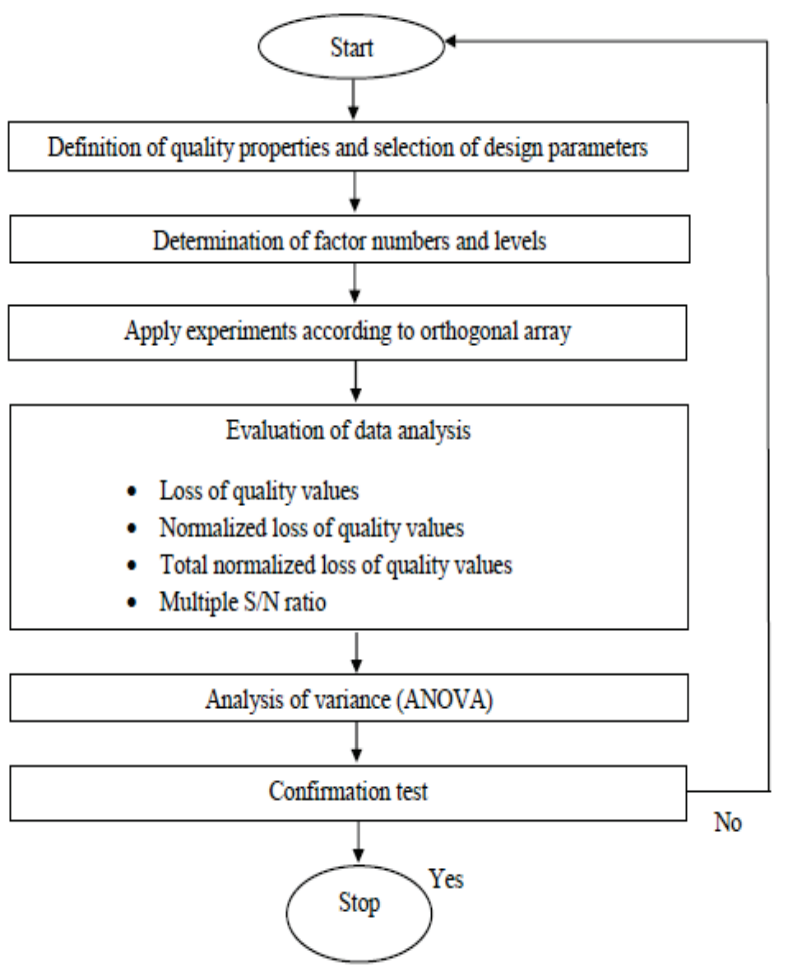

Figure 2 Flow chart for multi-objective optimization

Table 2 Control factors and their levels

\begin{tabular}{|c|c|c|c|c|c|}
\hline Symbol & Factor & Unit & Level 1 & Level 2 & Level 3 \\
\hline A & doc & $\mathrm{mm}$ & 0.5 & 1 & 1.5 \\
\hline B & $\mathrm{f}$ & $\mathrm{mm} / \mathrm{rev}$ & 0.08 & 0.12 & 0.16 \\
\hline C & $\mathrm{V}$ & $\mathrm{mm} / \mathrm{min}$ & 175 & 250 & 325 \\
\hline $\mathrm{D}$ & $\mathrm{N}$ & (pieces) & 1 & 2 & 3 \\
\hline
\end{tabular}

\section{Evaluation of data analysis:}

Multiple responses are transformed to single response using the Taguchi quality loss function. This optimization procedure is given below and explained.

1. Compute the quality loss $\left(L_{i j}\right)$

Quality loss can be classified into three categories: "larger-is-better", "smaller-is-better" and "normal-isbetter". In this study, the "smaller-is-better" category was selected for obtaining optimum machining parameters. Quality loss values for these responses were calculated using Eq. (1) and shown in Tab. 4.

$L_{i j}=\frac{1}{n_{i}} \sum_{k=1}^{n_{i}} y_{i j k}{ }^{2}$

where $n_{i}$ is the number of experiment repetition for the $i^{\text {th }}$ response, $y_{i j k}$ is the observed value for the $i^{\text {th }}$ response in the $k^{\text {th }}$ repetition of the $j^{\text {th }}$ experiment and $L_{i j}$ is the loss function of the $i^{\text {th }}$ response in the $j$ experiment. 
2. Establish the multi $\mathrm{S} / \mathrm{N}$ ratio (MSNR):

Step 1: Calculation of Normalized Quality Loss

$C_{i j}=\frac{L_{i j}}{L_{i}^{*}}$

$L_{i}^{*}=\max \left\{L_{i 1}, L_{i 2} \ldots, L_{i j}\right\}$

where $C_{i j}$ is the Normalized Quality Loss, $L_{i j}$ is the quality loss and $L_{i}^{*}$ is the maximum quality loss among the experimental runs. Normalized quality loss values for these responses were computed by using Eq. (2) and summarized in Tab. 5.

Step 2: Calculation of Total Normalized Quality Loss

$T N Q L_{j}=\sum_{i=1}^{m} w_{i} C_{i j}$

where $T N Q L_{j}$ is Total Normalized Quality Loss, $w_{i}$ is the weight of $i^{\text {th }}$ a normalized response $(i=1,2, \ldots, \mathrm{m}) . m$ is the number of response factors.

Table $3 \mathrm{~L}_{9}$ orthogonal design matrix and experimental results for $R a, R z$ and $R q$

\begin{tabular}{|c|c|c|c|c|c|c|c|c|c|c|c|c|c|c|c|c|}
\hline $\begin{array}{c}\text { Trial } \\
\text { No }\end{array}$ & $\begin{array}{c}d o c \\
(\mathrm{~mm})\end{array}$ & $\begin{array}{c}f \\
(\mathrm{~mm} / \mathrm{rev})\end{array}$ & $\begin{array}{c}V \\
(\mathrm{~m} / \mathrm{min})\end{array}$ & $\begin{array}{c}N \\
\text { (pieces) }\end{array}$ & $\begin{array}{l}R a 1 \\
(\mu \mathrm{m})\end{array}$ & $\begin{array}{l}R a 2 \\
(\mu \mathrm{m})\end{array}$ & $\begin{array}{l}R a 3 \\
(\mu \mathrm{m})\end{array}$ & $\begin{array}{c}\text { Ave. } \\
R a \\
(\mu \mathrm{m})\end{array}$ & $\begin{array}{l}R z 1 \\
(\mu \mathrm{m})\end{array}$ & $\begin{array}{l}R z 2 \\
(\mu \mathrm{m})\end{array}$ & $\begin{array}{l}R z 3 \\
(\mu \mathrm{m})\end{array}$ & $\begin{array}{c}\text { Ave. } \\
R z \\
(\mu \mathrm{m})\end{array}$ & $\begin{array}{l}R q 1 \\
(\mu \mathrm{m})\end{array}$ & $\begin{array}{l}R q 2 \\
(\mu \mathrm{m})\end{array}$ & $\begin{array}{l}R q^{3} \\
(\mu \mathrm{m})\end{array}$ & $\begin{array}{c}\text { Ave. } \\
R q \\
(\mu \mathrm{m})\end{array}$ \\
\hline 1 & 0.5 & 0.08 & 175 & 1 & 0.19 & 0.16 & 0.20 & 0.183 & 1.35 & 1.39 & 1.36 & 1.367 & 0.24 & 0.24 & 0.26 & 0.247 \\
\hline 2 & 0.5 & 0.12 & 250 & 2 & 0.25 & 0.27 & 0.30 & 0.273 & 1.90 & 1.95 & 1.85 & 1.900 & 0.31 & 0.36 & 0.38 & 0.350 \\
\hline 3 & 0.5 & 0.16 & 325 & 3 & 1.20 & 1.22 & 1.21 & 1.210 & 4.90 & 5.00 & 5.10 & 5.000 & 1.34 & 1.38 & 1.36 & 1.360 \\
\hline 4 & 1 & 0.08 & 250 & 3 & 0.46 & 0.52 & 0.50 & 0.493 & 2.32 & 2.47 & 2.41 & 2.400 & 0.54 & 0.60 & 0.61 & 0.583 \\
\hline 5 & 1 & 0.12 & 325 & 1 & 0.13 & 0.16 & 0.14 & 0.143 & 0.90 & 0.82 & 0.88 & 0.867 & 0.16 & 0.18 & 0.20 & 0.180 \\
\hline 6 & 1 & 0.16 & 175 & 2 & 0.48 & 0.53 & 0.47 & 0.493 & 2.70 & 3.00 & 2.90 & 2.867 & 0.61 & 0.60 & 0.65 & 0.620 \\
\hline 7 & 1.5 & 0.08 & 325 & 2 & 0.22 & 0.23 & 0.21 & 0.220 & 1.60 & 1.55 & 1.45 & 1.533 & 0.28 & 0.30 & 0.27 & 0.283 \\
\hline 8 & 1.5 & 0.12 & 175 & 3 & 1.03 & 1.08 & 1.06 & 1.057 & 4.40 & 4.35 & 4.25 & 4.333 & 1.15 & 1.25 & 1.13 & 1.177 \\
\hline 9 & 1.5 & 0.16 & 250 & 1 & 0.29 & 0.28 & 0.31 & 0.293 & 1.90 & 1.80 & 2.00 & 1.900 & 0.38 & 0.35 & 0.40 & 0.377 \\
\hline
\end{tabular}

Table 4 Quality loss values for $R a, R z$ and $R q$

\begin{tabular}{|c|c|c|c|}
\hline Exp. No & \multicolumn{3}{|c|}{ Quality Loss $(\mathrm{dB})$} \\
\hline & $\mathrm{Ra}$ & $\mathrm{Rz}$ & $\mathrm{Rq}$ \\
\hline 1 & 0.0339 & 1.8767 & 0.0609 \\
\hline 2 & 0.0751 & 3.6967 & 0.1239 \\
\hline 3 & 1.4642 & 25.0467 & 1.8499 \\
\hline 4 & 0.2448 & 5.7867 & 0.3423 \\
\hline 5 & 0.0217 & 0.7667 & 0.0343 \\
\hline 6 & 0.2459 & 8.3667 & 0.3882 \\
\hline 7 & 0.0485 & 2.3800 & 0.0804 \\
\hline 8 & 1.1186 & 18.8067 & 1.3873 \\
\hline 9 & 0.0869 & 3.6367 & 0.1432 \\
\hline
\end{tabular}

$T N Q L_{j}$ values have been determined by using Eq. 3. Then for each response, a weight $\left(w_{i}\right)$ was assigned, to indicate its importance relative to other responses. In this case each response has a different importance and weight. Weighting factors have been selected as $w_{1}=0.333, w_{2}=$ $0.333, \mathrm{w}_{3}=0.333$ for surface roughness. Multi signal-tonoise ratio $(M S N R)$ was calculated by using Eq. 4. TNQ $L_{j}$ and $M S N R_{j}$ values were given in Tab. 6 .

Table 5 Normalized quality loss values for $R a, R z$ and $R q$

\begin{tabular}{|c|c|c|c|}
\hline Exp. No & \multicolumn{3}{|c|}{ Normalized quality loss values } \\
\hline & $\mathrm{Ra}$ & $\mathrm{Rz}$ & $\mathrm{Rq}$ \\
\hline 1 & 0.0232 & 0.0749 & 0.0329 \\
\hline 2 & 0.0513 & 0.1476 & 0.0670 \\
\hline 3 & 1.0000 & 1.0000 & 1.0000 \\
\hline 4 & 0.1672 & 0.2310 & 0.1850 \\
\hline 5 & 0.0148 & 0.0306 & 0.0185 \\
\hline 6 & 0.1679 & 0.3340 & 0.2099 \\
\hline 7 & 0.0331 & 0.0950 & 0.0435 \\
\hline 8 & 0.7640 & 0.7509 & 0.7499 \\
\hline 9 & 0.0593 & 0.1452 & 0.0774 \\
\hline
\end{tabular}

Step 3: Determine the multi $\mathrm{S} / \mathrm{N}$ ratio (MSNR)

$$
M S N R_{j}=-10 \log \left(T N Q L_{j}\right)
$$

\begin{tabular}{|c|c|c|} 
Table 6 TNQL and MSNR values \\
\hline Exp. No & $T N Q L$ & $M S N R(\mathrm{~dB})$ \\
\hline 1 & 0.0437 & 13.598 \\
\hline 2 & 0.0886 & 10.524 \\
\hline 3 & 1.0000 & 0.000 \\
\hline 4 & 0.1944 & 7.113 \\
\hline 5 & 0.0213 & 16.713 \\
\hline 6 & 0.2373 & 6.248 \\
\hline 7 & 0.0572 & 12.426 \\
\hline 8 & 0.7549 & 1.221 \\
\hline 9 & 0.0940 & 10.269 \\
\hline
\end{tabular}

Table 7 Main effects of factors on MSNR

\begin{tabular}{|c|c|c|c|c|}
\hline \multirow{3}{*}{ Factor } & \multicolumn{4}{|c|}{$M S N R(\mathrm{~dB})$} \\
\hline & \multicolumn{3}{|c|}{ Level } & \\
\hline & 1 & 2 & 3 & Max-Min \\
\hline$d o c$ & 8.041 & $10.024^{*}$ & 7.972 & 2.052 \\
\hline$f$ & $11.045^{*}$ & 9.486 & 5.506 & 5.540 \\
\hline$V$ & 7.022 & 9.302 & $9.713^{*}$ & 2.691 \\
\hline$N$ & $13.527^{*}$ & 9.733 & 2.778 & 10.749 \\
\hline \multicolumn{5}{|c|}{ Optimal level } \\
\hline
\end{tabular}

3. Determine the optimal factor/level combinations

The effect of the control factors on the MSNR was obtained from Tab. 7. For the surface roughness parameters $R a, R z$ and $R q$, the MSNR graphs of the control factors are shown in Fig. 3. The best factor / level combination was identified as $A_{2} B_{1} C_{3} D_{1}$. The optimum levels of different control factors minimum surface roughness are $\mathrm{A}$ at level 2 
$(1 \mathrm{~mm})$ and $\mathrm{B}$ at level $1(0.08 \mathrm{~mm} / \mathrm{rev}), \mathrm{C}$ at level $3(325$ $\mathrm{m} / \mathrm{min})$, D at level 1 (1).

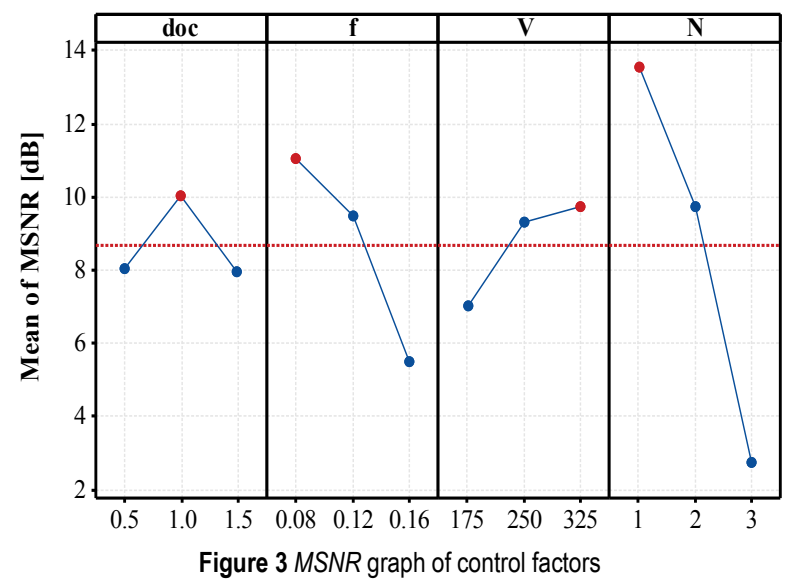

4. Variance analysis (ANOVA)

ANOVA was performed to calculate the effective factors on the surface roughness results and the contribution of these factors in the milling process (Tab. 8). From the ANOVA chart, the surface roughness parameters $R a, R z$ and $R q$ appear to be the most important factor in the feed rate. When the effect of the factors as a percentage is examined, it is seen that the effect of number of insert is $71.89 \%$, the effect of the feed rate is $19.74 \%$, the effect of the cutting speed is $5.08 \%$, and the effect of the depth of cut is $3.29 \%$. In conclusion, according to the ANOVA table, the most important factor to consider for surface roughness has been found to be the number of insert.

\begin{tabular}{|c|c|c|c|c|}
\hline Factors & $\begin{array}{l}\text { Degree of } \\
\text { freedom } \\
\text { (DOF) }\end{array}$ & $\begin{array}{c}\text { Sum of } \\
\text { squares (SS) }\end{array}$ & $\begin{array}{c}\text { Mean } \\
\text { square (MS) }\end{array}$ & $\begin{array}{c}\text { Percent } \\
\text { contribution } \\
\text { (PC) }\end{array}$ \\
\hline$d o c$ & 2 & 8.150 & 4.075 & 3.29 \\
\hline$f$ & 2 & 48.964 & 24.482 & 19.74 \\
\hline$V$ & 2 & 12.607 & 6.303 & 5.08 \\
\hline$N$ & 2 & 178.300 & 89.150 & 71.89 \\
\hline Total & 8 & 248.020 & & 100 \\
\hline
\end{tabular}

\section{Confirmation experiment}

The final step of the optimization process is to test the condition giving the optimal values to verify that the proposed improvement has been met. Verification test results are given in Tab. 9. In this work, the optimum result for the surface roughness as a result of milling process was reached under the experimental conditions $\mathrm{A}_{2} \mathrm{~B}_{1} \mathrm{C}_{3} \mathrm{D}_{1}$ test conditions. Eq. (5) was used to calculate $R a, R z$ and $R q$ of surface roughness values at optimal milling conditions determined by Taguchi technique. The estimated value of the MSNR at the optimum parameter levels $\left(\eta_{\mathrm{opt}}\right)$ is calculated.

$\eta_{\text {opt }}=\eta_{m}+\sum_{i=1}^{p}\left(\eta_{m i}-\eta_{m}\right)$ where $\eta_{o p t}$ is the predicted MSNR, $\eta_{m}$ is the overall average of the MSNR, $\eta_{m i}$ is the average MSNR at the optimum level, and $p$ is the number of the input factors that significantly influence the quality characteristic.

\begin{tabular}{|c|c|c|c|}
\hline \multirow{2}{*}{$\begin{array}{c}\text { Surface } \\
\text { roughness }\end{array}$} & \multirow{2}{*}{$\begin{array}{c}\text { Random } \\
\text { parameters }\end{array}$} & \multicolumn{2}{|c|}{ Optimum process parameters } \\
\hline & & Predicted & Experimental \\
\hline Level & $\mathrm{A}_{2} \mathrm{~B}_{1} \mathrm{C}_{2} \mathrm{D}_{3}$ & $\mathrm{~A}_{2} \mathrm{~B}_{1} \mathrm{C}_{3} \mathrm{D}_{1}$ & $\mathrm{~A}_{2} \mathrm{~B}_{1} \mathrm{C}_{3} \mathrm{D}_{1}$ \\
\hline $\mathrm{Ra}(\mu \mathrm{m})$ & 0.493 & & 0.117 \\
\hline $\mathrm{Rz}(\mu \mathrm{m})$ & 2.400 & & 0.933 \\
\hline $\mathrm{Rq}(\mu \mathrm{m})$ & 0.583 & & 0.143 \\
\hline MSNR (dB) & 7.113 & 18.273 & 17.359 \\
\hline
\end{tabular}

It is seen that an improvement of $10.246(\mathrm{~dB})$ in the MSNR when the optimal process parameter $\left(\mathrm{A}_{2} \mathrm{~B}_{1} \mathrm{C}_{3} \mathrm{D}_{1}\right)$ is used instead of the random parameter $\left(\mathrm{A}_{2} \mathrm{~B}_{1} \mathrm{C}_{2} \mathrm{D}_{3}\right)$. The results obtained from the confirmation experiments reflect the success of the multi-response optimization.

\section{CONCLUSIONS}

This study presented multi objective Taguchi technique to optimize performance parameters of AISI 4140 steel. The multiple quality characteristics were considered simultaneously using Taguchi quality loss function. The findings of the investigation are summarized as follows:

- The optimal levels of the machining parameters for minimum surface roughness for $R a, R z$ and $R q$ values were obtained to be $325 \mathrm{~m} / \mathrm{min}$ cutting speed, 0.08 $\mathrm{mm} / \mathrm{rev}$ feed rate, $1 \mathrm{~mm}$ depth of cut and 1 number of insert.

- $\quad R a, R z$ and $R q$ have been decreased down to $0.117 \mu \mathrm{m}$, $0.933 \mu \mathrm{m}$ and $0.143 \mu \mathrm{m}$, respectively against the random values of $R a, R z$ and $R q$ of $0.479 \mu \mathrm{m}, 2.400 \mu \mathrm{m}$ and $0.583 \mu \mathrm{m}$, respectively.

- The percent contribution of the control factors on the multiple quality characteristics was obtained to be number of insert $(71.89 \%)$, feed rate $(19.74 \%)$, cutting speed (5.08\%), and depth of cut (3.29\%) with ANOVA. The results show that the number of insert was found to be the significant factor among process parameters. The confirmation test conducted to determine optimal combination of machining parameters of AISI 4140 steel.

- Confirmation test results show that the increase of the MSNR ratio from the random input parameters to the optimal performance parameter was obtained to be $10.246 \mathrm{~dB}$. These results show that the multi response optimization technique by using a Taguchi quality loss function can significantly improve the quality performance characteristics of the milling process.

\section{REFERENCES}

[1] Groover, M. P. (2010) Principles of modern manufacturing $4^{\text {th }}$ edition, John Wiley \& Sons.

[2] Kalpakjian, S. (1995) Manufacturing Engineering and Technology $3^{\text {rd }}$ edition. Reading: Addison-Wesley. 
[3] El-Hofy, H. A. G. (2005) Advanced Machining Processes: Nontraditional and Hybrid Machining Processes 1st edition, McGraw-Hill.

[4] Kivak, T. (2014). Optimization of surface roughness and flank wear using the Taguchi method in milling of Hadfield steel with PVD and CVD coated inserts. Measurement, 50, 19-28. https://doi.org/10.1016/j.measurement.2013.12.017

[5] Stipkovic Filho, M., Stipkovic, M. A., Bordinassi, É. C., Delijaicov, S., \& de Almeida, S. L. R. (2018). Experimental Numerical Model of Roughness in Finishing Face Milling of AISI 4140 Hardened Steel. In Improved Performance of Materials (pp. 83-91). Springer, Cham. https://doi.org/10.1007/978-3-319-59590-0_8

[6] Sarıkaya, M., Yilmaz, V., \& Dilipak, H. (2016). Modeling and multi-response optimization of milling characteristics based on Taguchi and gray relational analysis. Proceedings of the Institution of Mechanical Engineers, Part B: Journal of Engineering Manufacture, 230(6), 1049-1065.

https://doi.org/10.1177/0954405414565136

[7] Ghani, J. A., Choudhury, I. A., \& Masjuki, H. H. (2004). Performance of P10 TiN coated carbide tools when end milling AISI H13 tool steel at high cutting speed. Journal of Materials Processing Technology, 153, 1062-1066. https://doi.org/10.1016/j.jmatprotec.2004.04.353

[8] Gopalsamy, B. M., Mondal, B., \& Ghosh, S. (2009). Taguchi method and ANOVA: An approach for process parameters optimization of hard machining while machining hardened steel. Journal of Scientific and Industrial Research, 68, 686695.

[9] Ab. Rashid, M. F. F, Gan, S. Y., \& Muhammad, N. Y. (2009). Mathematical modeling to predict surface roughness in CNC milling. World Academy of Science, Engineering and Technology, 53, 393-396.

[10] Patwari, M. A. U., Amin, A. K. M. N., \& Arif, M. D. (2011). Optimization of surface roughness in end milling of medium carbon steel by coupled statistical approach with genetic algorithm. Special Issue of the International Journal of the Computer, the Internet and Management, 19.

[11] Baek, D. K., Ko, T. J., \& Kim, H. S. (2001). Optimization of feedrate in a face milling operation using a surface roughness model. International Journal of Machine Tools and Manufacture, 41(3), 451-462. https://doi.org/10.1016/S0890-6955(00)00039-0

[12] Benardos, P. G. \& Vosniakos, G. C. (2002). Prediction of surface roughness in CNC face milling using neural networks and Taguchi's design of experiments. Robotics and ComputerIntegrated Manufacturing, 18(5-6), 343-354. https://doi.org/10.1016/S0736-5845(02)00005-4

[13] Routara, B. C., Bandyopadhyay, A., \& Sahoo, P. (2009). Roughness modeling and optimization in CNC end milling using response surface method: effect of workpiece material variation. The International Journal of Advanced Manufacturing Technology, 40(11-12), 1166-1180. https://doi.org/10.1007/s00170-008-1440-6

[14] Chhabada, M. V. \& Ambekar, S. D. (2016). Multi-response optimization of machining parameters on CNC milling of EN 19 Alloy Steel with TiAlN coated milling cutter using GRA. International Journal for Scientific Research \& Development, 4(5), 98-103.

[15] Mansour, A. \& Abdalla, H. (2002). Surface roughness model for end milling: a semi-free cutting carbon casehardening steel (EN32) in dry condition. Journal of Materials Processing Technology, 124(1-2), 183-191. https://doi.org/10.1016/S0924-0136(02)00135-8
[16] Gologlu, C. \& Sakarya, N. (2008). The effects of cutter path strategies on surface roughness of pocket milling of 1.2738 steel based on Taguchi method. Journal of materials processing technology, 206(1-3), 7-15. https://doi.org/10.1016/j.jmatprotec.2007.11.300

[17] Gupta, M. K. \& Sood, P. K. (2016). Optimizing multi characterstics in machining of AISI 4340 steel using Taguchi's approach and utility concept. Journal of The Institution of Engineers (India): Series C, 97(1), 63-69. https://doi.org/10.1007/s40032-015-0201-1

[18] Ross, P. J. (1988) Taguchi Techniques for Quality Engineering, McGray Hill, New York.

[19] Phadke, M. S. (1989) Quality Engineering Using Robust Design, Prentice-Hall, Englewood Cliffs, NJ.

[20] Terzi, U. \& Baynal, K. (2005). Concurrent optimization of multi response quality characteristics based on Taguchi method, $35^{\text {th }}$ International Conference on Computers and Industrial Engineering, 2, 1929-1934.

[21] Mohamed, M. A., Manurung, Y. H., \& Berhan, M. N. (2015). Model development for mechanical properties and weld quality class of friction stir welding using multi-objective Taguchi method and response surface methodology. Journal of Mechanical Science and Technology, 29(6), 2323-2331. https://doi.org/10.1007/s12206-015-0527-x

[22] Tong, L. I., Su, C. T., \& Wang, C. H. (1997). The optimization of multi-response problems in the Taguchi method. International Journal of Quality \& Reliability Management, 14(4), 367-380. https://doi.org/10.1108/02656719710170639

[23] Antony, J. (2001). Simultaneous optimisation of multiple quality characteristics in manufacturing processes using Taguchi's quality loss function. The International Journal of Advanced Manufacturing Technology, 17(2), 134-138. https://doi.org/10.1007/s001700170201

Authors' contacts:

Yusuf FEDAl, Assist. Prof. Dr.

Osmaniye Korkut Ata University

Department of Manufacturing Engineering,

80000 , Osmaniye, Turkey

E-mail: yusuffedai@osmaniye.edu.tr

Funda KAHRAMAN, Assoc. Prof. Dr.

Mersin University

Department of Mechatronics Engineering,

80000 , Mersin, Turkey

E-mail: fkahraman@mersin.edu.tr

Hediye KIRLI AKIN, Assist. Prof. Dr.

Osmaniye Korkut Ata University

Department of Manufacturing Engineering,

80000 , Osmaniye, Turkey

E-mail: hediyeakin@osmaniye.edu.tr

Gokhan BASAR, Res. Assist.

Osmaniye Korkut Ata University

Department of Manufacturing Engineering,

80000, Osmaniye, Turkey

E-mail: gokhanbasar@osmaniye.edu.tr 